\title{
INTERMEDIATE SPECIES IN THE POLYMERIZATION OF ISOCYANIDES
}

\section{P C J KAMER, R J M NOLTE*,**, W DRENTH**}

Department of Organic Chemustry, University at Utrecht, Padualaan 8, $3584 \mathrm{CH}$ Utrecht (The Netherlands)

\section{H L L M NIJS and J A KANTERS}

Laboratory for Crystal and Structural Chemistry, Unversity at Utrecht, Padualaan 8, 3584 CH Utrecht (The Netherlands)

(Received December 10, 1987, accepted July 6, 1988)

\section{Summary}

Isocyanides polymerize under the catalytic action of nickel(II) salts, $n \mathrm{R}-\mathrm{N}^{+} \equiv \mathrm{C}^{-} \rightarrow[\mathrm{R}-\mathrm{N}=\mathrm{C}<]_{n}$. The mechanism of the polymerization reaction has been investigated. The first intermediate is a square planar nickel(II) isocyanide complex. The general structure of this kind of complex was confirmed by an X-ray analysis of one particular complex, viz tetrakıs(2,6dusopropylphenyl isocyanide)nickel(II) perchlorate The polymerization is initiated by the attack of a nucleophile (in our case an amine) on a coordinated isocyanide The initiation proceeds in two steps, (1) coordination of the amine to the nickel centre, and (11) migration of the amine to the isocyano carbon atom. The resulting product is a nickel carbene complex. The propagation step is an insertion reaction of an isocyanide into the nickel-carbene bond. The polymerization propagates via a consecutive series of such insertion reactions around the nickel centre.

\section{Introduction}

Isocyanides polymerize under the catalytic action of $\mathrm{N}_{1}(\mathrm{II})$ salts $[1,2]$. The resulting polymers are called poly(1socyanides), poly(iminomethylenes) or poly(carbonimidoyls). The polymers have a rigid helical structure and

$n \mathrm{R}-\mathrm{N}^{+} \equiv \mathrm{C}^{-} \stackrel{\mathrm{Ni}(\mathrm{II})}{\longrightarrow}[\mathrm{R}-\mathrm{N}=\mathrm{C}<]_{n}$

are, therefore, chiral. This chirality is caused by restricted rotation around the carbon-carbon single bonds of the polymer main chain. Stereoisomerism resulting from this type of chirality is called atropisomerism [3]

\footnotetext{
*Present address University at Nımegen, 6525 ED Niymegen, The Netherlands

**Authors to whom correspondence should be addressed
} 
In the past, a mechanism was proposed for the polymerization of isocyanides catalysed by nickel(II) [1]. Addition of an excess of isocyanide to nickel chloride in ethanol gives a red solution with spectral characteristics similar to those found for the square planar $\mathrm{N}_{1}(\mathrm{C} \equiv \mathrm{N})_{4}{ }^{2-}$ ion. Therefore, we assumed that a simlar complex $\left(\imath e \quad\left[\mathrm{Nl}(\mathrm{C} \equiv \mathrm{N}-\mathrm{R})_{4}\right]^{2+}\right)$ is the predomlnant species under polymerization conditions $[4,5]$. Kinetic measurements showed that the polymerization is first order in nickel chloride as well as in isocyanide $[6,7]$ The activation entropy, $\Delta S^{\ddagger}$, of the polymerization of isopropyl isocyanide in ethanol was estimated to be $-54 \pm 13 \mathrm{~J} \mathrm{~mol}^{-1}$ $\mathrm{K}^{-1}$ [6]. This value is of the same order of magnitude as those observed for hgand substitutions in square planar platinum complexes [8]. The activation enthalpy, $\Delta H^{\ddagger}$, was found to be $61.4 \pm 4 \mathrm{~kJ} \mathrm{~mol}^{-1}[6]$. On the basis of these results, it was concluded that the polymerization is initiated by nucleophilic attack on a coordinated isocyanide, and proceeds via a series of consecutive insertion reactions around the nickel(II) centre However, the intermediates of the polymerization reaction could not be isolated The proposed structure of these intermediates was based on the structure of similar palladium and platinum complexes [9].

In the present paper we describe the isolation and characterization of the first intermediates in the polymerization of isocyanides.

\section{Results and discussion}

As nucleophiles initiate the polymerization of isocyanides, we chose the non-nucleophilic $\mathrm{ClO}_{4}^{-}$ion as the counterion for the preparation of our nickel isocyanide complexes Stephany and Drenth [4] have already shown that complexes such as $\mathrm{N}_{1}\left(\mathrm{CN}-\mathrm{t}-\mathrm{C}_{4} \mathrm{H}_{9}\right)_{4} \mathrm{X}_{2}$ can be isolated when $\mathrm{ClO}_{4}^{-}$is the counterion (with $\mathrm{X}=\mathrm{Cl}^{-}$the polymerization process interfered).

The characterization of $\mathrm{N}_{1}\left(\mathrm{C} \equiv \mathrm{N}-\mathrm{t}-\mathrm{C}_{4} \mathrm{H}_{9}\right)_{4}\left(\mathrm{ClO}_{4}\right)_{2}$ is hampered by the low solubility of this complex Therefore, we synthesized the complexes $\mathrm{N} 1\left(\mathrm{C} \equiv \mathrm{N}-\mathrm{t}-\mathrm{C}_{5} \mathrm{H}_{11}\right)_{4}\left(\mathrm{ClO}_{4}\right)_{2} \quad(1)$ and $\mathrm{N} 1\left[\mathrm{C} \equiv \mathrm{N}-2,6-\mathrm{d} 1\left(1-\mathrm{C}_{3} \mathrm{H}_{7}\right) \mathrm{C}_{6} \mathrm{H}_{3}\right]_{4}\left(\mathrm{ClO}_{4}\right)_{2}$ (2), which have better solubility and could even be crystallized The crystal structure analysis of 2 confirms that the complex is centrosymmetric, the nickel(II) ion is the centre of the complex. The bond angle between the isocyanide carbons and nickel is $92.3^{\circ}$ Therefore, the complex has a square planar structure (see Fig. 1). The bond angles $\mathrm{C} \equiv \mathrm{N}-\mathrm{C}$ of the coordinated socyanides show a deviation from linearity of only $5.5^{\circ}\left(\mathrm{C}^{11} \mathrm{~N}^{1} \mathrm{C}^{1}\right)$ and $6.7^{\circ}\left(\mathrm{C}^{21} \mathrm{~N}^{2} \mathrm{C}^{2}\right)$, which is in line with the high sp character of the $\mathrm{N}$ orbitals The $\mathrm{N} \equiv \mathrm{C}$ bond lengths, moreover, he also in the range expected for sp hybridized atoms $1.146\left(\mathrm{C}^{1} \mathrm{~N}^{1}\right)$ and $1.160\left(\mathrm{C}^{2} \mathrm{~N}^{2}\right) \AA$. The $\mathrm{N}-\mathrm{C}$ bond lengths are $1.829\left(\mathrm{NiC}^{1}\right)$ and $1838\left(\mathrm{NiC}^{2}\right) \AA$; the $\mathrm{N}-\mathrm{C}$ bond lengths are $1.41\left(\mathrm{~N}^{1} \mathrm{C}^{11}\right)$ and $142\left(\mathrm{~N}^{2} \mathrm{C}^{21}\right) \AA$. The aromatic rings make angles with the plane formed by the nickel centre and the isocyanide carbon atoms. These angles amount to $577^{\circ}$ (ring 1 ) and $71.8^{\circ}$ (ring 2). 


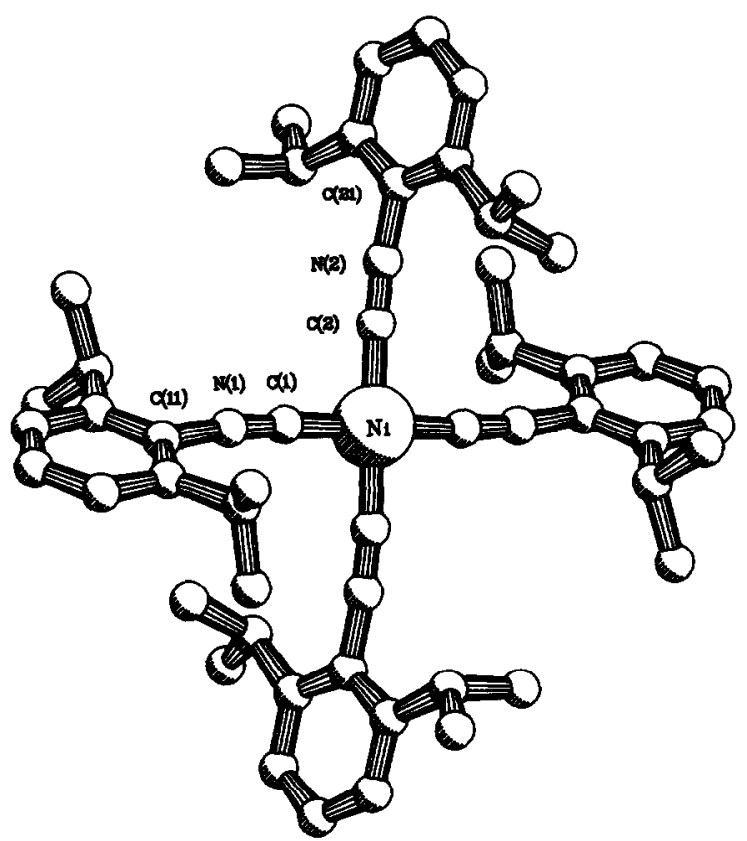

Fig 1 X-ray structure of tetrakis(2,6-disopropylphenyl isocyanide) nickel(II) perchlorate

TABLE 1

IR stretching frequencies of the $\mathrm{N} \equiv \mathrm{C}$ bond in free isocyanides and nickel(II) isocyanide complexes

\begin{tabular}{lll}
\hline $\mathrm{R}$ & $\begin{array}{l}\nu(\mathrm{N} \equiv \mathrm{C}) \\
\text { in R-N } \\
\left(\mathrm{cm}^{-1}\right)\end{array}$ & $\begin{array}{l}\nu(\mathrm{N} \equiv \mathrm{C}) \\
\text { in } \mathrm{N}_{1}\left(\mathrm{C}^{-} \equiv \mathrm{C}^{-}\right. \\
\left(\mathrm{cm}^{-1}\right)\end{array}$ \\
\hline $\mathrm{t}-\mathrm{C}_{4} \mathrm{H}_{9}$ & 2140 & 2245 \\
$\mathrm{t}-\mathrm{C}_{5} \mathrm{H}_{11}$ & 2131 & 2223 \\
$2,6-\mathrm{di}_{1}-\left(1-\mathrm{C}_{3} \mathrm{H}_{7}\right) \mathrm{C}_{6} \mathrm{H}_{3}$ & 2120 & 2222 \\
\hline
\end{tabular}

aMeasured in dry $\mathrm{CH}_{2} \mathrm{Cl}_{2}$

Further information can be obtained from the infrared spectra of 1 and 2. The $\mathrm{N} \equiv \mathrm{C}$ stretching frequencies of the free and coordinated isocyanides are given in Table 1 . On coordination of the 1socyanide, the $\mathrm{N} \equiv \mathrm{C}$ stretching frequency shifts approximately $100 \mathrm{~cm}^{-1}$ upwards, and is found at $2223 \mathrm{~cm}^{-1}$ for complex 1 and at $2222 \mathrm{~cm}^{-1}$ for complex 2 . This is in the range of the $\mathrm{N} \equiv \mathrm{C}$ stretching vibration of cyanides, which also have $\mathrm{sp}$ hybridized orbitals The appreciable shift in $\nu(\mathrm{N} \equiv \mathrm{C})$ means that of the two resonance structures $\mathrm{R}-\dot{\mathrm{N}}=\mathrm{C}: \leftrightarrow \mathrm{R}-\mathrm{N}^{+} \equiv \mathrm{C}:^{-}$, the latter will become more important after coordmation. The values of $\nu(\mathrm{N} \equiv \mathrm{C})$ indicate that the isocyanide ligand in 1 and 2 is more a $\sigma$ donor than a $\pi$ acceptor, a 
feature often observed when isocyanides coordinate to high-valent metal centres [10].

In the ${ }^{13} \mathrm{C}$ NMR spectrum, the isocyanide carbon resonance has shifted from $1551 \mathrm{in}$ the free ligand [11] to $113.7 \mathrm{ppm}$ in complex 1. This upfield shift is often observed when socyanides coordinate to metal ions [12]. The UV spectrum of complex 1 shows two strong bands at $\lambda=239 \mathrm{~nm}$ $\left(\epsilon=12300 \mathrm{dm}^{3} \mathrm{~mol}^{-1} \mathrm{~cm}^{-1}\right), \lambda=274 \mathrm{~nm}\left(\epsilon=7590 \mathrm{dm}^{3} \mathrm{~mol}^{-1} \mathrm{~cm}^{-1}\right)$, and a weak broad band at about $\lambda=335 \mathrm{~nm}\left(\epsilon=40 \mathrm{dm}^{3} \mathrm{~mol}^{-1} \mathrm{~cm}^{-1}\right)$. This UV spectrum is almost identical to that of the complex $\mathrm{N}\left(\mathrm{C} \equiv \mathrm{N}-\mathrm{t}-\mathrm{C}_{4} \mathrm{H}_{9}\right)_{4^{-}}$ $\left(\mathrm{ClO}_{4}\right)_{2}$ isolated by Stephany and Drenth [4].

Coordinated isocyanides are sensitive to attack by a nucleophile [10]. Alcohols and amines are known to react with coordinated isocyanide to give carbene complexes [12]. We therefore presumed that the initiating step in the polymerization of ssocyanides was the attack of a nucleophile on the coordmated socyanide [5]. We treated complex 1 with one equivalent of $(S)-(-)-1$-phenylethylamine* and observed that the reaction proceeded in two steps. When the reaction is carried out at $-60{ }^{\circ} \mathrm{C}$, intermediate 3 is formed, which is stable for some time (Fig. 2). Complex 3 is

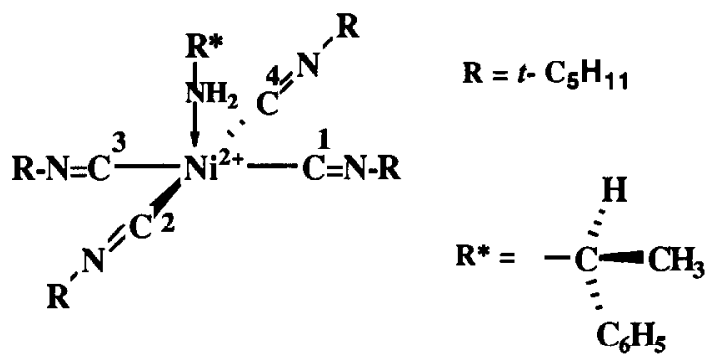

Fig 2 Structure of intermediate 3

red in colour, whereas complex 1 is yellow. In the IR spectrum of 3 , two $\mathrm{NH}$ stretching frequencies are seen at 3300 and $3250 \mathrm{~cm}^{-1}$. These frequencies are $\sim 30 \mathrm{~cm}^{-1}$ lower than those found for free 1-phenylethylamine. The two NH signals are indicative of a primary amine. Therefore, we concluded that in complex 3 the amine is coordinated to the nickel centre. On coordination of the amine, the symmetry of the nickel isocyanide complex changes, and as a result a different pattern of the $\mathrm{N} \equiv \mathrm{C}$ stretching frequency will be observed. This is indeed the case. Complex 3 has an strong $(\mathrm{N} \equiv \mathrm{C})$ absorption at $2233 \mathrm{~cm}^{-1}$ and a shoulder at $2242 \mathrm{~cm}^{-1} \mathrm{~A}$ medium-sized absorption is present at $2202 \mathrm{~cm}^{-1}$, with a shoulder at 2188 $\mathrm{cm}^{-1}$ When the temperature is slowly increased, the IR spectrum changes The two NH stretching frequencies gradually disappear and are transformed to one signal at $3280 \mathrm{~cm}^{-1}$, characteristic of a secondary amme. A new

*An optically active amune was used in order to obtain optically active poly(isocyanides) using the described complex as catalyst, see also [13] 


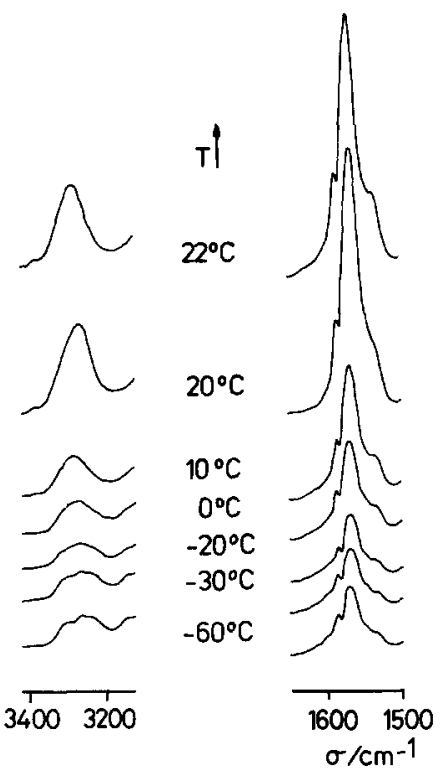

Fig 3 Change in IR spectrum of complex 3 when raising the temperature from -60 to $22{ }^{\circ} \mathrm{C}$

signal arises at $1570 \mathrm{~cm}^{-1}$ with a shoulder at $1585 \mathrm{~cm}^{-1}$, while a medium peak is observed at $1537 \mathrm{~cm}^{-1}$ The change in these signals as a function of the temperature is shown in Fig. 3. Changes also occur in the $\mathrm{C} \equiv \mathrm{N}$ stretching region. At $20{ }^{\circ} \mathrm{C}$ a strong absorption is observed at $2220 \mathrm{~cm}^{-1}$, with shoulders at 2240 and $2190 \mathrm{~cm}^{-1}$. The signals at 1570 and $1585 \mathrm{~cm}^{-1}$ lie in the range observed for the $\mathrm{N}-\mathrm{C}=\mathrm{N}$ stretching vibrations in metal ( $\mathrm{Pd}$, $\mathrm{Pt}, \mathrm{N} 1)$ carbene complexes [9]. We propose that at elevated temperatures a nickel carbene complex 4 is formed from 3 . This would agree with the observation that a primary amine is converted into a secondary amine (Fig. 4)

If the conversion of complex 1 to 4 proceeds va complex 3 , the UV spectrum of 1 will change and, because complexes 1 and 4 both have a square planar arrangement of ligands, will eventually return to approximately the original spectrum. In Fig. 5 the change is shown in the UV

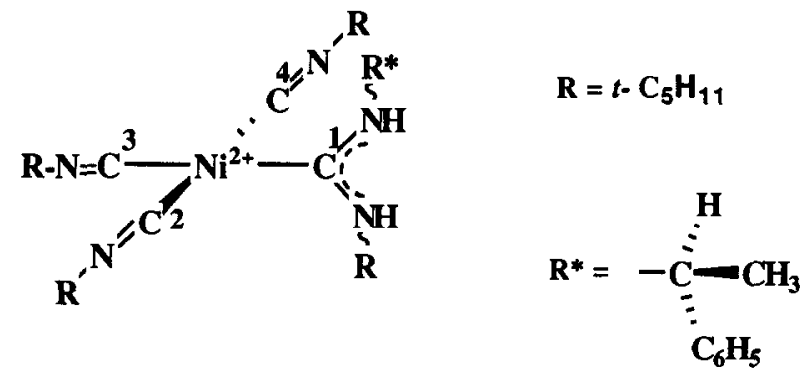

Fig 4 Structure of the nickel carbene complex 4 


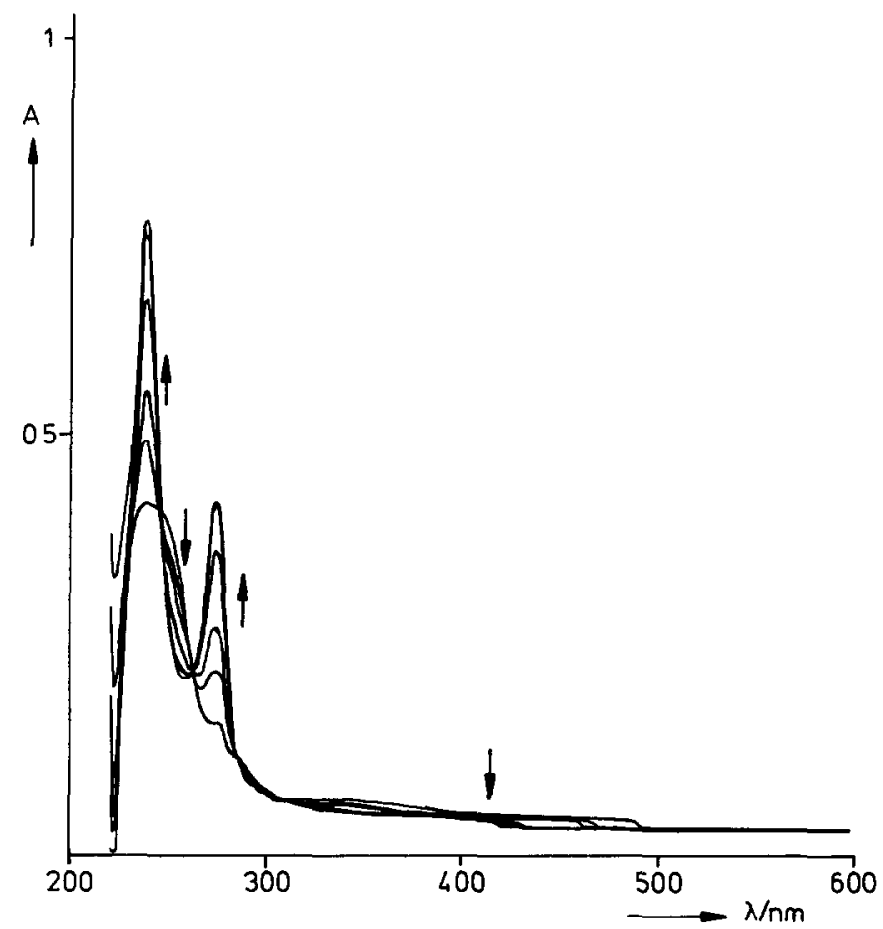

Fig 5 Change in UV spectrum of complex 3 when raising the temperature from -60 to $22{ }^{\circ} \mathrm{C}$ Arrows indicate the main changes

spectrum of the reaction mixture on increasing the temperature from -60 to $20{ }^{\circ} \mathrm{C}$ The UV spectrum at $-60{ }^{\circ} \mathrm{C}$ indeed is totally different from that of the starting complex 1 The UV absorptions appear at $\lambda=420 \mathrm{~nm}$ (broad signal; $\epsilon=450 \mathrm{dm}^{3} \mathrm{~mol}^{-1} \mathrm{~cm}^{-1}$ ), $\lambda=340 \mathrm{~nm}$ (broad signal; $\epsilon=820$ $\left.\mathrm{dm}^{3} \mathrm{~mol}^{-1} \mathrm{~cm}^{-1}\right), \lambda=273 \mathrm{~nm}\left(\epsilon=2760 \mathrm{dm}^{3} \mathrm{~mol}^{-1} \mathrm{~cm}^{-1}\right), \lambda=250 \mathrm{~nm}(\epsilon=$ $\left.7880 \mathrm{dm}^{3} \mathrm{~mol}^{-1} \mathrm{~cm}^{-1}\right)$, and $\lambda=238 \mathrm{~nm}\left(\epsilon=8430 \mathrm{dm}^{3} \mathrm{~mol}^{-1} \mathrm{~cm}^{-1}\right)$. At $20{ }^{\circ} \mathrm{C}$ the spectrum of the reaction mixture is quite analogous to the spectrum of the starting complex 1 . Several isosbestic points are observed, indicating that we are dealing with the transformation of one compound into another.

In analogy to similar known complexes, the plane of the ligand $\mathrm{C}\{\mathrm{NH}$ $\left.\mathrm{CH}\left(\mathrm{CH}_{3}\right) \mathrm{C}_{6} \mathrm{H}_{5}\right\} \mathrm{NH}-\mathrm{t}-\mathrm{C}_{5} \mathrm{H}_{11}$ will be approximately perpendicular to the plane formed by the nickel ion and the isocyanide carbons [9]

The ${ }^{1} \mathrm{H}$ NMR spectrum of the five-coordinated complex 3 at $-60{ }^{\circ} \mathrm{C}$ showed only broad signals, suggesting that the complex is paramagnetic. The magnetic susceptibility of 3 was determined by the Evans method [14] The $\mu$-value amounted to $1.2 \mathrm{BM}$, which corresponds to 056 unpaured electrons. Since an amine is a two-electron donor, the number of unpared electrons is expected to be even. The observed low value of 0.56 may be ascribed to the reaction of complex 3 to form 4 during the preparation of the sample and the susceptiblity measurement 
The carbene complex 4 is diamagnetic and showed well-resolved ${ }^{1} \mathrm{H}$ and ${ }^{13} \mathrm{C}$ NMR spectra. The ${ }^{13} \mathrm{C}$ NMR spectrum was especially informative about the structure of the complex. Two ${ }^{13} \mathrm{C}$ resonances, at 1754 and $1792 \mathrm{ppm}$, are observed in the region where carbenic carbon signals are to be expected [15-17]. The fact that two signals are present suggests that complex 4 occurs in two conformations. In line with this, two signals with almost the same intensity ratio are found for the other carbon atoms of the carbene ligand: 141.6 and $142.5 \mathrm{ppm}\left(\mathrm{C}^{1}\right.$ of the phenyl ring); 54.1 and $61.1(\mathrm{CH}) ; 58.3$ and $59.7\left[\mathrm{~N}-\mathrm{C}\left(\mathrm{CH}_{3}\right)_{2} \mathrm{C}_{2} \mathrm{H}_{5}\right], 33.3$ and $35.5\left(\mathrm{CH}_{2}\right) ; 26.5$ and $28.2\left[\mathrm{C}\left(\mathrm{CH}_{3}\right)_{2}\right], 23.0$ and $23.8\left[\mathrm{CH}\left(\mathrm{CH}_{3}\right)\right]$ A simular phenomenon was observed for the complex $\mathrm{Nl}\left(\mathrm{C} \equiv \mathrm{N}-\mathrm{t}-\mathrm{C}_{4} \mathrm{H}_{9}\right)_{3}\left[\mathrm{C}\left\{\mathrm{NHCH}\left(\mathrm{CH}_{3}\right) \mathrm{C}_{6} \mathrm{H}_{5}\right\} \mathrm{NH}-\right.$ t- $\left.\mathrm{C}_{4} \mathrm{H}_{9}\right]\left(\mathrm{ClO}_{4}\right)_{2}$, where the carbene hgand can have three conformations [18] In principle four conformations are possible, which are shown in Fig. 6. Molecular models suggest that, for steric reasons, conformations 6B and $6 \mathrm{D}$ are not possible When t-butyl isocyanide is used instead of t-pentyl isocyanide, conformation $6 B$ is possible [18]. Simlar observations have been reported by Crocianı and Richards, who studied the conformations of palladium and platınum carbene complexes [19]. The most likely conformations are $6 \mathrm{~A}$ and $6 \mathrm{C}$. We believe that conformation $6 \mathrm{~A}$ is more probable than $6 \mathrm{C}$, because the phenyl nng can interact with the nickel centre.

A

B
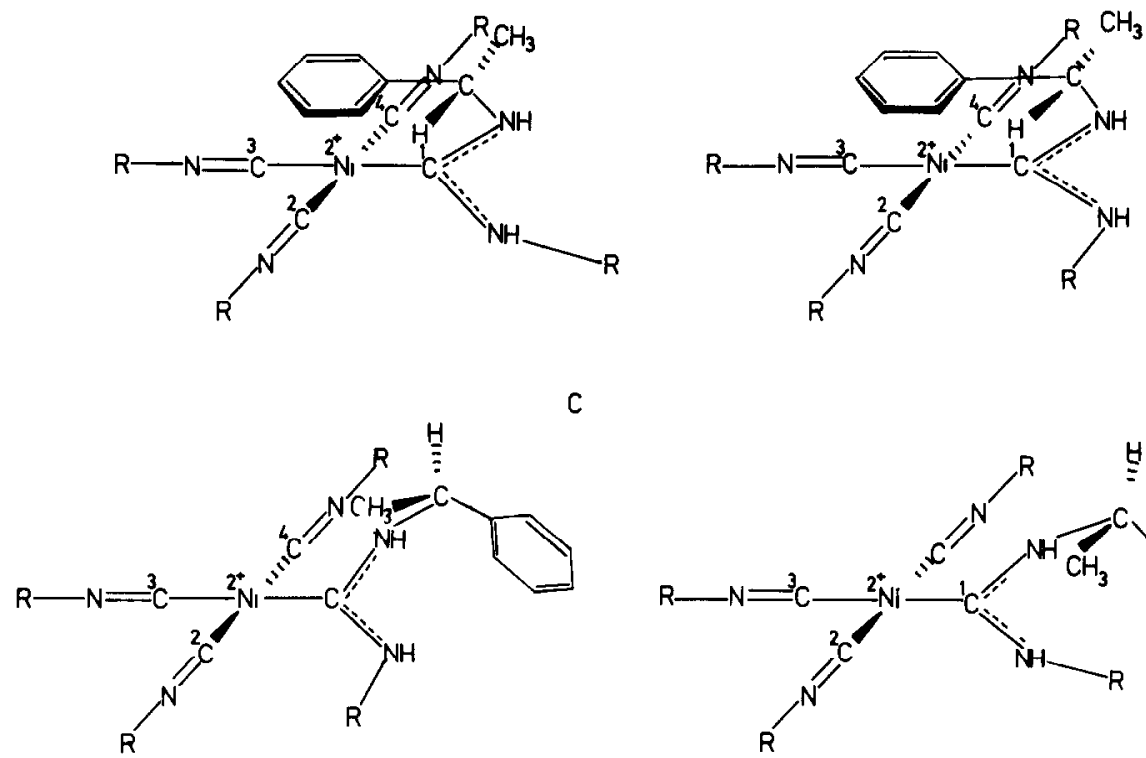

C

Fig 6 Possible conformations of $\mathrm{N}\left(\mathrm{C} \equiv \mathrm{N}-\mathrm{t}-\mathrm{C}_{5} \mathrm{H}_{11}\right)_{3}\left[\mathrm{C}\left\{\mathrm{NHCH}\left(\mathrm{CH}_{3}\right) \mathrm{C}_{6} \mathrm{H}_{5}\right\} \mathrm{NH}-\mathrm{t}-\mathrm{C}_{5} \mathrm{H}_{11}\right]-$ $\left(\mathrm{ClO}_{4}\right)_{2}$ (complex 4) 


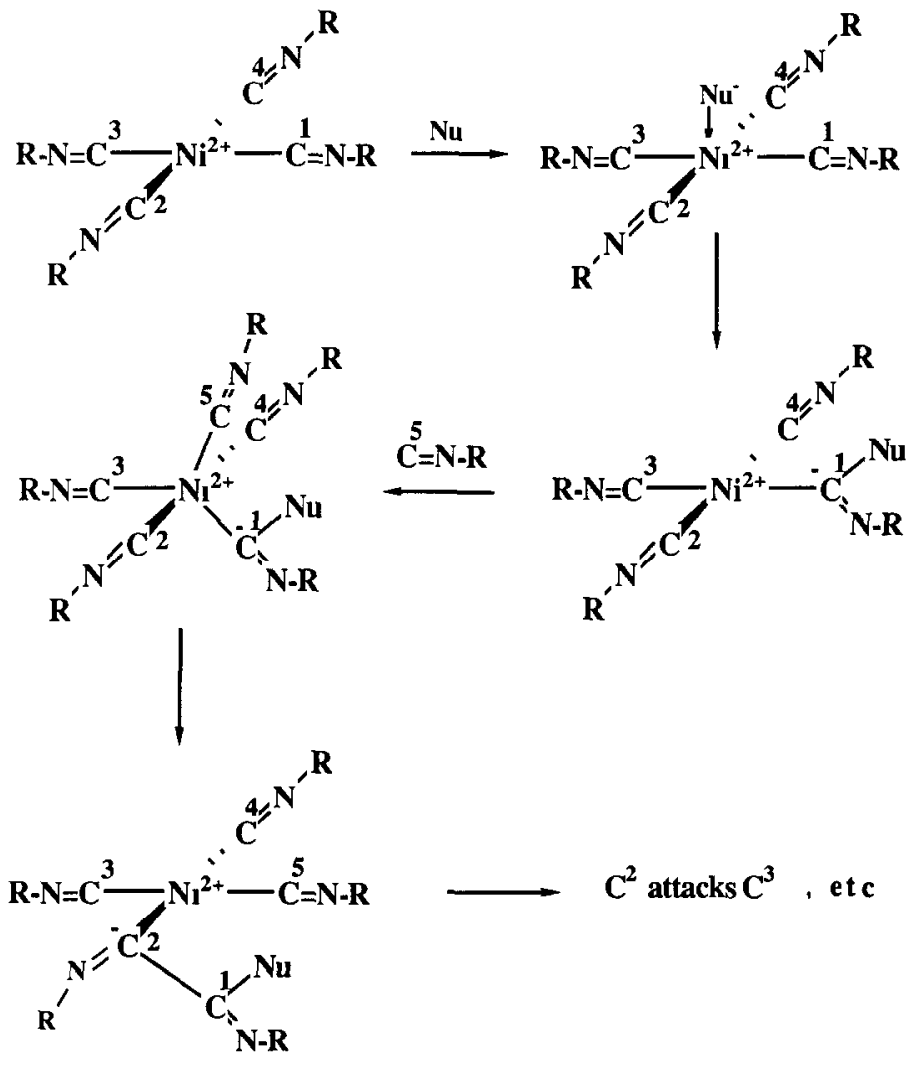

Fig 7 Mechanism of the polymerization

Moreover, the phenyl ring causes less steric hindrance than the t-pentyl substituent with respect to the bulky nickel centre*.

The experiments described here confirm that the initiation step of the polymerization of ssocyanides, resulting in a nickel carbene complex, is in line with the original proposal of Drenth and Nolte (see Fig. 7) [1]. Isocyanides are known to insert into metal-carbene bonds [12]. We therefore believe that a series of consecutive insertions is the most likely description of the propagation steps. However, attempts to isolate the intermediate formed in the first propagation step have so far been unsuccessful.

\section{Experimental section}

\section{Analytıcal techniques}

Infrared (IR) spectra were recorded on Perkın-Elmer 297 and 283 spectrophotometers. Ultraviolet (UV) spectra were recorded on a Perkın-

*As a relative measure of steric hindrance, the $\lambda$-steric parameter can be used See also [20], where $(R, \lambda R) \mathrm{H}, 000, \mathrm{CH}_{3}, 100, \mathrm{C}_{6} \mathrm{H}_{5}, 123, \mathrm{t}-\mathrm{C}_{4} \mathrm{H}_{9}, 149$ 
Elmer 200 spectrophotometer Optical rotations were measured on a PerkınElmer 241 polarimeter ${ }^{1} \mathrm{H}$ NMR spectra were obtained on Varan EM 390 and Bruker WP 200 instruments. ${ }^{13} \mathrm{C}$ NMR spectra were recorded on a Bruker WP 200 instrument; chemical shifts $(\delta)$ are given in ppm downfield from internal tetramethylsilane. Abbreviations used are $s=$ singulet, $d=$ doublet, $\mathrm{t}=$ triplet, $\mathrm{q}=$ quartet, $\mathrm{m}=$ multiplet, and $\mathrm{br}=$ broad. Melting points were determined on a Mettler FP5/FP51 photoelectric melting point apparatus. Crystallographıc data were collected with an Enraf-Nonıus CAD 4 diffractometer.

\section{N-Formyl-t-pentylamine}

According to a literature procedure t-pentylamine was $N$-formylated with a $10 \%$ excess of ethyl formate in $67 \%$ yield. IR (neat) $1675(\mathrm{C}=\mathrm{O})$ $\mathrm{cm}^{-1} ;{ }^{1} \mathrm{H}$ NMR $\left(\mathrm{CDCl}_{3}\right) \delta 8.3-7.8(\mathrm{~m}, 1 \mathrm{H}, \mathrm{CHO}), 7.3-5.3(\mathrm{br}, 1 \mathrm{H}, \mathrm{NH})$, $160\left(2 \times \mathrm{q}, 2 \mathrm{H}, \mathrm{CH}_{2}\right), 1.30\left(2 \times \mathrm{s}, 6 \mathrm{H}, \mathrm{CH}_{3}\right), 0.90\left(2 \times \mathrm{t}, 3 \mathrm{H}, \mathrm{CH}_{3}\right)$

\section{$t$-Pentyl zsocyanide}

This socyanide was prepared from $N$-formyl-t-pentylamine by the method of Schuster et al. [21] but at a lower pressure $(0.5 \mathrm{mmHg})$ than recommended Yield 88\%; IR $\left(\mathrm{CCl}_{4}\right) 2131(\mathrm{C}=\mathrm{N}) \mathrm{cm}^{-1} ;{ }^{1} \mathrm{H} \mathrm{NMR}\left(\mathrm{CDCl}_{3}\right)$ $\delta 1.63\left(3 \times \mathrm{q}, 2 \mathrm{H}, \mathrm{CH}_{2}\right), 1.37\left(3 \times \mathrm{s}, 6 \mathrm{H}, \mathrm{CH}_{3}\right), 1.03\left(\mathrm{t}, 3 \mathrm{H}, \mathrm{CH}_{3}\right)$.

\section{N-Formyl-2,6-dusopropylanuline}

In $200 \mathrm{~cm}^{3}$ of dry $\mathrm{CH}_{2} \mathrm{Cl}_{2}, 60 \mathrm{~g}$ of 2,6 -dusopropylaniline $(0.34 \mathrm{~mol})$ was dissolved and cooled in an ice bath. A mixture of $40 \mathrm{~cm}^{3}$ of formic acid (106 mol) and $40 \mathrm{~cm}^{3}$ of acetic anhydride was sturred for $1 \mathrm{~h}$ and then added to the above-mentioned solution at such a rate that the temperature remained between 5 and $10{ }^{\circ} \mathrm{C}$ Subsequently, the reaction mixture was stirred for $60 \mathrm{~h}$ at room temperature and refluxed for $4 \mathrm{~h}$. The solvent was evaporated under vacuum, and the residue was dissolved in $\mathrm{CHCl}_{3}$ and washed three times with a saturated aqueous $\mathrm{NaHCO}_{3}$ solution and with water The organic layer was dried over $\mathrm{Na}_{2} \mathrm{SO}_{4}$ and the solvent was evaporated in vacuum. The product was recrystallized from diethyl ether: yeld $47 \mathrm{~g}(66 \%)$; m.p. $160{ }^{\circ} \mathrm{C}$, IR (KBr) $1660(\mathrm{C}=\mathrm{O}) \mathrm{cm}^{-1},{ }^{1} \mathrm{H}$ NMR (CD$\left.\mathrm{Cl}_{3}\right) \delta 82-7.6(\mathrm{~m}, 2 \mathrm{H}, \mathrm{CH}), 1.28\left(\mathrm{~d}, 12 \mathrm{H}, \mathrm{CH}_{3}\right)$.

\section{2,6-Dusopropylphenyl usocyanide}

This isocyanide was synthesized from $N$-formyl-2,6-dissopropylaniline according to a modification of the method of Skorna and Ug1 [22] The procedure was as follows. Into a round-bottomed flask equipped with a magnetic sturrer and a $\mathrm{CO}_{2}$ /acetone reflux condenser kept at $-30{ }^{\circ} \mathrm{C}$, were brought $179 \mathrm{~g} \mathrm{~N}$-formyl-2,6-dusopropylaniline $(87 \mathrm{mmol}), 20 \mathrm{~cm}^{3}$ of dry $N$-methylmorpholine $(180 \mathrm{mmol})$ and $150 \mathrm{~cm}^{3}$ of dry $\mathrm{CH}_{2} \mathrm{Cl}_{2}$ as solvent. Over a period of $1 \mathrm{~h}, 3.9 \mathrm{~cm}^{3}$ of diphosgene $(45 \mathrm{mmol})$ in $50 \mathrm{~cm}^{3}$ of dry $\mathrm{CH}_{2} \mathrm{Cl}_{2}$ was introduced into the stirred reaction muxture at a temperature of $-30^{\circ} \mathrm{C}$. Stirring was continued for another hour. The cooling bath was 
removed and $100 \mathrm{~cm}^{3}$ of water was immediately added to the reaction mixture. The still cold organic layer was separated, washed three times with $100 \mathrm{~cm}^{3}$ of an aqueous $5 \% \mathrm{NaHCO}_{3}$ solution and once with $100 \mathrm{~cm}^{3}$ of water. The $\mathrm{CH}_{2} \mathrm{Cl}_{2}$ layer was dried over $\mathrm{Na}_{2} \mathrm{SO}_{4}$ The crude reaction product was purified by column chromatography (slica gel, $\mathrm{CH}_{2} \mathrm{Cl}_{2}$ ): yield $12.4 \mathrm{~g}$ (72\%) of a colorless liquid, IR $\left(\mathrm{CH}_{2} \mathrm{Cl}_{2}\right) 2120(\mathrm{C}=\mathrm{N}) \mathrm{cm}^{-1} ;{ }^{1} \mathrm{H}$ NMR $\delta 7.06$ $\left(\mathrm{m}, 3 \mathrm{H}, \mathrm{C}_{6} \mathrm{H}_{3}\right), 332(\mathrm{~m}, 2 \mathrm{H}, \mathrm{CH}), 117\left(\mathrm{~d}, 12 \mathrm{H}, \mathrm{CH}_{3}\right)$.

\section{(S)-(-)-1-Phenylethylamine}

Racemic 1-phenylethylamine was resolved in its optical antipodes by a standard method [23]. The specific optical rotation of the (S)-enantiomer was $[\alpha]_{\mathrm{D}}^{20}-403^{\circ}$ (neat) [lit $[11][\alpha]_{\mathrm{D}}^{29}-39.4^{\circ}$ (neat)].

\section{Tetrakıs(t-pentyl isocyanide)nickel(II) perchlorate}

This complex was prepared according to a literature procedure by adding 4 equiv of t-pentyl isocyanide to a stirred $020 \mathrm{M}$ solution of N1$\left(\mathrm{ClO}_{4}\right)_{2} \cdot 6 \mathrm{H}_{2} \mathrm{O}$ in $96 \%$ ethanol/ether $13(\mathrm{v} / \mathrm{v})$ at $0{ }^{\circ} \mathrm{C}$ [4]. The complex separated from the solution and was collected by filtration, washed with cold ethanol/ether and with cold ether. The complex was dried at $40^{\circ} \mathrm{C}$ at $002 \mathrm{mmHg}$ Yield 80\% IR $\left(\mathrm{CH}_{2} \mathrm{Cl}_{2}\right) 2223(\mathrm{C}=\mathrm{N}) \mathrm{cm}^{-1} ;{ }^{1} \mathrm{H} \mathrm{NMR}\left(\mathrm{CDCl}_{3}\right)$ $\delta 1.89\left(\mathrm{q}, 2 \mathrm{H}, \mathrm{CH}_{2}\right), 163\left(\mathrm{~s}, 6 \mathrm{H}, \mathrm{CH}_{3}\right), 1.15\left(\mathrm{t}, 3 \mathrm{H}, \mathrm{CH}_{3}\right) ;{ }^{13} \mathrm{C} \mathrm{NMR}\left(\mathrm{CDCl}_{3}\right)$ $\delta 113.71(\mathrm{~s}, \mathrm{C}=\mathrm{N}), 64.91\left(\mathrm{~s}, \underline{\mathrm{C}}\left(\mathrm{CH}_{3}\right)_{2} \mathrm{CH}_{2}\right), 34.29\left(\mathrm{~s}, \mathrm{CH}_{2}\right), 26.97(\mathrm{~s}$, $\left.\mathrm{C}\left(\mathrm{CH}_{3}\right)_{2}\right), 814\left(\mathrm{~s}, \mathrm{CH}_{2} \mathrm{CH}_{3}\right)$, UV $\left(\mathrm{CH}_{2} \mathrm{Cl}_{2}\right) \lambda(\epsilon) 335$ (40), 274 (7590), 239 (12 300); elemental analysis. $\mathrm{C}_{24} \mathrm{H}_{44} \mathrm{Cl}_{2} \mathrm{~N}_{4} \mathrm{NrO}_{8}$ (646 25): calcd.: $\mathrm{C}, 44.61$; $\mathrm{H}, 6.86 ; \mathrm{Cl}, 1097 ; \mathrm{N}, 867 ; \mathrm{N}, 9.08, \mathrm{O}, 19.81 \%$; found: $\mathrm{C}, 44.51 ; \mathrm{H}, 6.83$; $\mathrm{Cl}, 1088 ; \mathrm{N}, 8.63 ; \mathrm{N}_{1}, 9.22 ; \mathrm{O}, 19.81 \%$.

\section{Tetrakıs(2,6-dusopropylphenyl ssocyanide)nuckel(II) perchlorate}

Th1s complex was prepared as described for $\mathrm{N} 1\left(\mathrm{C} \equiv \mathrm{N}-\mathrm{t}-\mathrm{C}_{5} \mathrm{H}_{11}\right)_{4}\left(\mathrm{ClO}_{4}\right)_{2}$, but the solvent was $96 \%$ ethanol/ether $1: 1(\mathrm{v} / \mathrm{v})$. The yield was $76 \%$. A small sample of the product was dissolved in a minimum amount of tetrahydrofuran and the solution was stored at $-30^{\circ} \mathrm{C}$ The product crystallized after one day and crystals were selected for X-ray analysis Some crystallographic data. Space group $\mathrm{P}_{b c a} z=4$, with $a=19.15(1), b=21.04(1)$, $c=15$ 91(1). Full detalls of the analysis will be published elsewhere [24] IR $\left(\mathrm{CH}_{2} \mathrm{Cl}_{2}\right) 2222(\mathrm{C}=\mathrm{N}) \mathrm{cm}^{-1} ;{ }^{1} \mathrm{H} \mathrm{NMR}\left(\mathrm{CDCl}_{3}\right) \delta 7.1\left(\mathrm{~m}, 3 \mathrm{H}, \mathrm{C}_{6} \mathrm{H}_{3}\right)$, $3.5(\mathrm{~m}, 2 \mathrm{H}, \mathrm{CH}), 1.25\left(\mathrm{~d}, 12 \mathrm{H}, \mathrm{CH}_{3}\right)$; elemental analysis. $\mathrm{C}_{52} \mathrm{H}_{68} \mathrm{Cl}_{2} \mathrm{~N}_{4} \mathrm{NiO}_{8}$ (1006.81): calcd. $\mathrm{C}, 62.03 ; \mathrm{H}, 6.81 ; \mathrm{Cl}, 7.04 ; \mathrm{N}, 5.57 ; \mathrm{N1}, 5.83 ; \mathrm{O}, 1271 \%$; found: $\mathrm{C}, 6188 ; \mathrm{H}, 6.67 ; \mathrm{Cl}, 7.12, \mathrm{~N}, 5.50 ; \mathrm{N1}, 590 ; \mathrm{O}, 12.70 \%$.

Tri(t-pentyl isocyanide([S)-(-)-1-phenylethylamino(t-pentylamino)carbene] nickel(II) perchlorate

In $10 \mathrm{~cm}^{3}$ of dry $\mathrm{CH}_{2} \mathrm{Cl}_{2}, 441.4 \mathrm{mg}$ of tetrakıs(t-pentyl isocyanide)nickel(II) perchlorate $(0.68 \mathrm{mmol})$ was dissolved. At $20^{\circ} \mathrm{C} 86.9 \times 10^{-3}$ $\mathrm{cm}^{3}$ of $(S)-(-)-1$-phenylethylamine $(0.68 \mathrm{mmol})$ was added. The yellow solution turned orange-red and after a few minutes the color reverted to 
yellow. After sturring for $15 \mathrm{~min}$ the $\mathrm{CH}_{2} \mathrm{Cl}_{2}$ was removed under vacuum and the complex was dried at $20{ }^{\circ} \mathrm{C}$ and $001 \mathrm{mmHg}$. Yield $100 \%$ of a yellow powder: $[\alpha]_{\mathrm{D}}^{20} 9.3^{\circ}\left(c 0.45, \mathrm{CHCl}_{3}\right)$; IR $\left(\mathrm{CH}_{2} \mathrm{Cl}_{2}\right) 3280(\mathrm{NH}) ; 3059(\mathrm{CH}$ arom.); 2974, 2939 and 2880 (CH aliph); 2220, 2240 (sh) and 2190 (sh) $(\mathrm{C}=\mathrm{N}) ; 1570,1585(\mathrm{sh})$ and $1537(\mathrm{~N}-\mathrm{C}-\mathrm{N}) ; 1090$ and $620\left(\mathrm{ClO}_{4}^{-}\right) \mathrm{cm}^{-1}$; ${ }^{1} \mathrm{H} \mathrm{NMR}\left(\mathrm{CDCl}_{3}\right) \delta 8.78$ and $6.67(2 \times \mathrm{d}, 2 \mathrm{H}, \mathrm{CHNH}), 8.02$ and $6.33(2 \times$ $\mathrm{s}, 2 \mathrm{H}, \mathrm{NH}), 762-7.28\left(\mathrm{~m}, 5 \mathrm{H}, \mathrm{C}_{6} \mathrm{H}_{5}\right), 5.83$ and $4.99(2 \times \mathrm{m}, 1 \mathrm{H}, \mathrm{CH})$, $1.92-0.47(\mathrm{~m}$, remaining $\mathrm{H}) ;{ }^{13} \mathrm{C}$ NMR $\left(\mathrm{CDCl}_{3}\right) \delta 179.2$ and $175.4(2 \times \mathrm{s}$, $\mathrm{C}$ carbene), 142.5 and $141.6\left(2 \times \mathrm{s}, \mathrm{C}^{1}\right.$ arom.), $1293-126.1$ (m, $\mathrm{C}$ arom.), $123.4(\mathrm{br}, \mathrm{C}=\mathrm{N}), 64.2(\mathrm{br}, \mathrm{C}-\mathrm{N}=\mathrm{C}), 61.1$ and $54.1(2 \times \mathrm{s}, \mathrm{CH}), 59.7$ and $58.3(2 \times \mathrm{s}, \mathrm{C}-\mathrm{NH}), 35.5$ and $33.3\left(2 \times \mathrm{s}, \mathrm{CH}_{2}-\mathrm{C}-\mathrm{NH}\right), 34.5\left(\mathrm{~s}, \mathrm{CH}_{2}-\mathrm{C}-\right.$ $\mathrm{N}=\mathrm{C}), 28.2$ and $265\left(2 \times \mathrm{s},\left(\mathrm{CH}_{3}\right)_{2} \mathrm{CNH}\right), 27.1\left(\mathrm{~s},\left(\mathrm{CH}_{3}\right)_{2} \mathrm{C}-\mathrm{N}=\mathrm{C}\right), 238$ and $23.0\left(2 \times \mathrm{s}, \underline{\mathrm{C}} \mathrm{H}_{3} \mathrm{CH}\right), 8.2\left(\mathrm{~s}, \underline{\mathrm{CH}}_{3} \mathrm{CH}_{2} \mathrm{C}-\mathrm{N}=\mathrm{C}\right), 7.8\left(\mathrm{~s}, \mathrm{CH}_{3} \mathrm{CH}_{2} \mathrm{CNH}\right)$, FAB mass spectrum m/e $666\left(\mathrm{M}^{-} \mathrm{ClO}_{4}^{-}\right)^{+}, 569\left(\mathrm{M}-\mathrm{ClO}_{4}^{-}-\mathrm{t}_{-} \mathrm{C}_{5} \mathrm{H}_{11} \mathrm{NC}\right)^{+}$, $505\left(\mathrm{M}-2 \mathrm{ClO}_{4}^{-}-\mathrm{t}-\mathrm{C}_{5} \mathrm{H}_{11} \mathrm{NC}+\mathrm{Cl}^{-}\right)^{+}, 373\left(\mathrm{M}-2 \mathrm{ClO}_{4}^{-}-2 \mathrm{t}-\mathrm{C}_{5} \mathrm{H}_{11} \mathrm{NC}\right)^{+}, 311$ $\left(\mathrm{M}-2 \mathrm{ClO}_{4}^{-}-3 \mathrm{t}-\mathrm{C}_{5} \mathrm{H}_{11} \mathrm{NC}+\mathrm{Cl}^{-}\right)^{+}, 276\left(\mathrm{M}-2 \mathrm{ClO}_{4}^{-}-3 \mathrm{t}-\mathrm{C}_{5} \mathrm{H}_{11} \mathrm{NC}\right)^{+}$, elemental analysis: $\mathrm{C}_{32} \mathrm{H}_{55} \mathrm{Cl}_{2} \mathrm{~N}_{5} \mathrm{NlO}_{8}(767.43) \cdot$ calcd.: $\mathrm{C}, 50.08 ; \mathrm{H}, 7.22 ; \mathrm{Cl}, 9.24$; $\mathrm{N}, 9.13 ; \mathrm{Nl}, 7.65 ; \mathrm{O}, 16.67 \%$; found: $\mathrm{C}, 50.06 ; \mathrm{H}, 7.29 ; \mathrm{Cl}, 9.25 ; \mathrm{N}, 910$, $\mathrm{Nl}, 7.63 ; \mathrm{O}, 16.65 ; \mathrm{UV}\left(\mathrm{CH}_{2} \mathrm{Cl}_{2}\right) \lambda(\epsilon) \cdot 248$ (11800), 281 (5370), 330 (310).

\section{References}

1 W Drenth and R J M Nolte, Acc Chem Res, 12 (1979) 30

2 F Millich, Macromol Rev, 15 (1980) 207

3 E L Elıel, Stereochemustry of Carbon Compounds, McGraw-Hill, New York, 1962, p 156

4 R W Stephany and W Drenth, Recl Trav Chım Pays-Bas, 91 (1972) 1453

5 R J M Nolte, J W Zwikker, J Reedık and W Drenth, J Mol Catal, 4 (1978) 423

6 R J M Nolte and W Drenth, Recl Trav Chim Pays-Bas, 92 (1973) 788

7 R J M Nolte, Thesis, Univ Utrecht, 1973

8 F Basolo and R G Pearson, Mechantsm of Inorgantc Reactions, Wiley, New York, $1976, \mathrm{p} 404$

9 (a) E M Badley, J Chatt, $R$ L Richard and G A Sim, $J$ Chem Soc, Chem Commun, (1969) 1322, (b) W M Butler and J H Enemark, Inorg Chem, 12 (1973) 540, (c) R F Stepaniak and N C Payne, Inorg Chem, 13 (1974) 797, (d) K P Wagner, $P$ M Treichel and J C Calabrese, J Organometall Chem, 71 (1974) 299, (e) A Modinos and P Woodward, J Chem Soc, Dalton Trans, (1974) 2065, (f) P Domiano, A Musattı, M Nardellı and G Predierı, J Chem Soc, Dalton Trans, (1975) 2165

10 P M Treschel, Adv Organometall Chem, 11 (1973) 21

11 R W Stephany, Thesss, Unuv of Utrecht, 1973

12 E Singleton and H E Oosthuizen, Adv Organometall Chem, 22 (1984) 209

13 P C J Kamer, $R$ J $M$ Nolte and $W$ Drenth, $J$ Chem Soc, Chem Commun, (1986) 1789

14 D F Evans, J Chem Soc (1959) 2003

15 P R Branson, $R$ A Cable, $M$ Green and $M K$ Lloyd, $J$ Chem Soc, Chem Commun, (1974) 364 
16 U Plaia, H Stolzenberg and W P Fehlhammer, J Am Chem Soc, 107 (1985) 2171

17 W P Fehlhammer, K Bartel, U Plaia, A Volkl and A $T$ Liu, Chem Ber, 118 (1985) 2235

18 P C J Kamer, R J M Nolte and W Drenth, Recl Trav Chım Pays-Bas, 107 (1988) 175

19 B Crocian and R L Richards, $J$ Chem Soc, Dalton Trans, (1974) 693

20 H B Kagan, Stereochemistry, Vol 3, Thieme-Stuttgart, 1977, p 26

21 R E Schuster, J E Scott and J Casanova, Org Synth, 46 (1966) 75.

22 G Skorna and I Ug1, Angew Chem, 89 (1977) 267

23 A Ault, Org Synth, 49 (1969) 93

24 H L L M Nijs, J A Kanters, P C J Kamer, R J M Nolte and W Drenth, Acta Cryst $C$, to be submitted 